\title{
Hegedűs Szilárd
}

\section{Eladósodás és tőkeszerkezet vizsgálata a kvázi-fiskális szektorban Magyarországon}

\author{
Szilárd Hegedús \\ Examining the Leverage and Capital Structure of the Quasi Fiscal Sector \\ in Hungary
}

\begin{abstract}
Összefoglalás
Az önkormányzati alrendszer szervezeti struktúrájából adódóan nem csupán a hagyományos módon, költségvetési szervek közremüködésével látja el a feladatait, hanem a helyhatóságok gazdasági társaságokat is alapíthatnak a közfeladat ellátására, melyet a törvény a hatás-és feladatkörükbe utalt. Ennek megfelelöen a helyhatóságok a feladataikat a tulajdonukban lévó önkormányzati cégek közremüködésével látnak el. Az önkormányzati adósságállomány konszolidálásra került 2013-ig, azonban az önkormányzati cégek azonban kockázatot jelentenek a tulajdonos önkormányzatoknak, valamint az alrendszer pénzügyi kockázatait jelentik. A tanulmányban a megyei jogú városok és a Föváros tulajdonában lévő önkormányzati vállalatok adósságállományának alakulását vizsgálom 2006-2013 között, melynek célja, hogy milyen mértékben jelentenek kockázatot a tulajdonosok, az önkormányzatok számára.

Kulcsszvak: Önkormányzati vagyongazdálkodás, vállalatok, adósságállomány, elemzés, kockázatok
\end{abstract}

\section{Summary}

As regards the selection of the tasks of the municipality sector, the local authorities have freedom both according to the former and the current legislation. The advantages of performing tasks through companies owned by the municipality include the flexible adaptation to market conditions and integration into the relation network of the economy. Some research works have proved, however, that their operation is rather risky. In the frames of the research I reviewed the reports of companies and compared the indices formed, evaluating primarily the profitability, indebtedness, asset structure and solvency. In regard to the liabilities of the examined companies, the dominance of short-term liabilities, increasing receivables and the profitable management were clear phenomena in most cases within the sample.

Keywords: risk, corporate finances, leverage, analysis, contingent liabilities, public sector

\section{BEVEZETÉS}

Az önkormányzati tulajdonú profit és nonprofit társaságok gazdálkodnak az önkormányzati vagyonnal, valamint fejlesztik, bővítik azt, illetve a lakosság számára fontos közszolgáltatásokat biztosítanak, ennek a rendszerét a helyhatóságok szabadon alakíthatják ki, hisz a szolgáltatások megszervezéséért, nem biztosításáért felelősek (Vigvári, 2009; Szabó, 2012). Az új önkormányzati törvény szabályozásában átrendeződtek a feladat - és hatáskörök, illetve 
lezajlott az önkormányzatok adósságkonszolidációja, így az adósságállományból eredő pénzügyi kockázat lecsökkent (Lentner, 2014).

Az adósságkonszolidáció azonban nem terjedt ki a kvázi fiskális szektorra, így az adósság kérdésköre releváns az önkormányzatokhoz szervesen kapcsolódó, ám számvitelileg nem konszolidált önkormányzati cégeket illetően. Tanulmányunkban arra keressük a választ, hogy milyen pénzügyi egészség jellemzi a megyei jogú városok önkormányzatai által birtokolt vállalatokat, milyen gazdálkodási folyamat jellemzi a kvázi fiskális szektor vállalatait, valamint, hogy milyen jellegú kockázatok jellemzik a vizsgált vállalati kört.

\section{IRODALMI ÁTTEKINTÉS}

Az önkormányzati rendszer kockázatait számos hazai irodalom vizsgálta, tipizálta és rendszerezte. Ezek a kockázatok a szervezeti háttérből, illetve pénzügyi, vagyoni típusú kockázatokból erednek.

Az utóbbi kockázati tényezőket Vigvári Jánossy az eladósodás, bonitás, likviditás kockázataiként értelmezett, melynek okai túlzott mértékú beruházási aktivitás (ÁSZ, 2011), illetve a központi költségvetés nem a települési struktúrákkal és adottságokkal konzisztens finanszírozása, melyek közül különösen a kötvénykibocsátás és hitelfelvétel volt jelentős mértékű a témák szempontjából fontos megyei jogú városi önkormányzatok körében. 2012-2013 között lezajlott az önkormányzatok adósságkonszolidációja, illetve a sarkalatos törvényekkel, mindenekelőtt a Stabilitásról szóló törvénnyel megvalósult a hitelfelvételi újraszabályozása. A szabályozás korábbiakhoz képest szigorodott azzal, hogy bizonyos instrumentumok esetében hitelfelvétel engedélykötelessé vált, például a kötvénykibocsátás esetében.

A kvázi fiskális szektor legnagyobb kockázataként értékeli a szakirodalom a feltételes kötelezettségvállalás (contigent liability) jelenségét, mely értelmezése szerint az önkormányzatok olyan kapcsolatokat létesítenek a magángazdaság szereplőivel, melyek esetleges veszteségei későbbiekben az önkormányzatra vagy a központi költségvetésre hárulnak. (Polackova, 1998; Schick, 1999; Hegedűs - Tönkő, 2007)

E tekintetben megnyilvánuló kockázat az önkormányzati gazdasági társaság hitelfelvétele mögött lévő esetleges tulajdonosi garanciavállalás. Ez nem szerepel az önkormányzat beszámolójában, ugyanakkor az önkormányzatok rugalmatlan bevételszerzési és kiszámíthatatlan finanszírozása miatt jelentős kockázatokat idézhet elő az önkormányzatok gazdálkodásában. Vigvári (2009) megállapításai alapján elsősorban a megyei jogú városok önkormányzatait érinti. Hasonló problémák léphetnek fel az önkormányzati társaságok túlzott mértékű eladósodása, és veszteséges múködés esetén, hiszen ezeket a tevékenységeket az önkormányzatok nem szüntethetik meg veszteséges múködés során, így a tulajdonosként kell helyt állniuk a vállalataik kötelezettségeiért. Ebból adódóan kockázatként értékeli a szakirodalom e vállalatok transzparens múködésének hiányát. (Vigvári, 2009; Hegedús - Tönkő, 2006)

$\mathrm{Az}$ önkormányzatok feladat-és hatáskörének reformja keretében differenciáltan kerültek meghatározásra az önkormányzatok feladatai, melyben a megyei jogú városok tekintetében is érvényesül. Méretükből, szerepkörükből adódóan nagyobb területi egységek, lakosság ellátására kötelezettek, különösen a közszolgáltatások területén. Erre körre jellemző a stratégiaalkotás, mely kiterjed a települések fejlesztésén túl az egyes ágazatok fejlesztésére is. ( Sisa - Veress, 2015)

$\mathrm{Az}$ önkormányzati gazdaság részeiként megjelennek a szolgáltatásmenedzsment koordinálásáért felelős szervek, melyet a választópolgárok választanak meg (képviselőtestület, polgármester és bizottságok), költségvetési szervként múködő feladatellátó szervek, illetve az önkormányzatokhoz kapcsolt, szervezetileg azonban elkülönült gazdasági társaságok, valamint nonprofit szervezetek. 
2011-től az Állami Számvevőszéki ellenőrzések is vizsgálják az önkormányzati tulajdonú gazdasági társaságokat. Főbb megállapításait tekintve az önkormányzati cégek egyre nagyobb szerepet játszanak a kötelező és önként vállalt feladatok ellátásában. Problémát okoz a kockázatok megfelelő értékelésében, hogy az államszámvitel szemléletváltása ellenére sem lehetséges a konszolidálhatóság, a számviteli alapelvek inkonzisztenciája miatt. (Szabó, 2012) Az Állami Számvevőszék vizsgálatai alapján a megyei jogú városok körében a garanciavállalások, kezességek megnégyszereződtek 2007 és 2010 között, különösen a Fővárosi Önkormányzatnál jelentősek a kockázatok, melyek a lejárt tartozásokból, kezességekből adódnak.

\section{ANYAG ÉS MÓDSZER}

1. táblázat: A vizsgálati minta bemutatása

\begin{tabular}{|cccc|}
\hline Vizsgált évek & Megyei jogú városok & Föváros & Összesen \\
\hline $\mathbf{2 0 0 6}$ & 139 & 18 & 157 \\
\hline $\mathbf{2 0 0 7}$ & 140 & 19 & 159 \\
\hline $\mathbf{2 0 0 8}$ & 204 & 28 & 232 \\
\hline $\mathbf{2 0 0 9}$ & 205 & 30 & 235 \\
\hline $\mathbf{2 0 1 0}$ & 235 & 34 & 269 \\
\hline $\mathbf{2 0 1 1}$ & 236 & 37 & 273 \\
\hline $\mathbf{2 0 1 2}$ & 238 & 27 & 265 \\
\hline $\mathbf{2 0 1 3}$ & 238 & 26 & 264 \\
\hline & & Forrás: saját kutatás, 2015
\end{tabular}

A vizsgált vállalatokat tekintve a minta tartalmaz átalakulással létrejött, jogelőd illetve jogelőd nélkül alapított vállalkozásokat. Ahogyan láthatjuk az önkormányzati vállalati létszám folyamatosan növekvő tendenciát követett a megyei jogú városoknál, és különösen dinamikus bővülést a kerületi önkormányzatok tekintetében. A csökkenő összlétszám a Főváros vállalatainak számának visszaesése miatt következett be, több önkormányzati holdingtársaság (BVK Zrt.) létrehozásából adódóan, ezeket a vállalatokat a konszolidált beszámoló miatt csak az anyavállalatként vettem figyelembe. $A z$ önkormányzati cégeknél kétirányú folyamat zajlott le, egyrészt a cégalapítási hullám, mely 2008-ban mutatkozott meg, másrészt az önkormányzati holdingokba történő szervezése az általánosan profitorientált vállalati körnek. Az új cégek alapítása elsődlegesen a non-profit szektorban volt jellemző, szociális foglalkoztatás, kultúra területén.
Az első hipotézisem, hogy az önkormányzati tulajdonú gazdasági társaságok kötelezettségei hasonlóan a tulajdonos önkormányzatokéhoz növekvő tendenciát követ a vizsgált periódusban.

A második hipotézisem, hogy érvényesül a Roxburgh hipotézis, mely krizisek esetén a kötelezettségállomány késeltetett csökkenésével reagálnak a vállalatok forrásszerkezetük kialakitásánál, igy válságos években csak évekkel késóbb érvényesül a kötelezettségek csökkenése (Szemán, 2013)

A harmadik hipotézisem szerint beruházási ciklushatás érvényesül az önkormányzati cégek tökeszerkezetében, mely azt jelenti, hogy hasonlóan az önkormányzatokhoz a vállalataik esetében is befolyásolják a tôkeszerkezetet a választási évek által meglévő ciklushatások, így választási években növekszik az adósságállomány. (Vigvári, 2008) 


\section{1. ábra: A megyei jogú városok önkormányzatainak aggregált vállalati tőkeszerkezeti adatai}

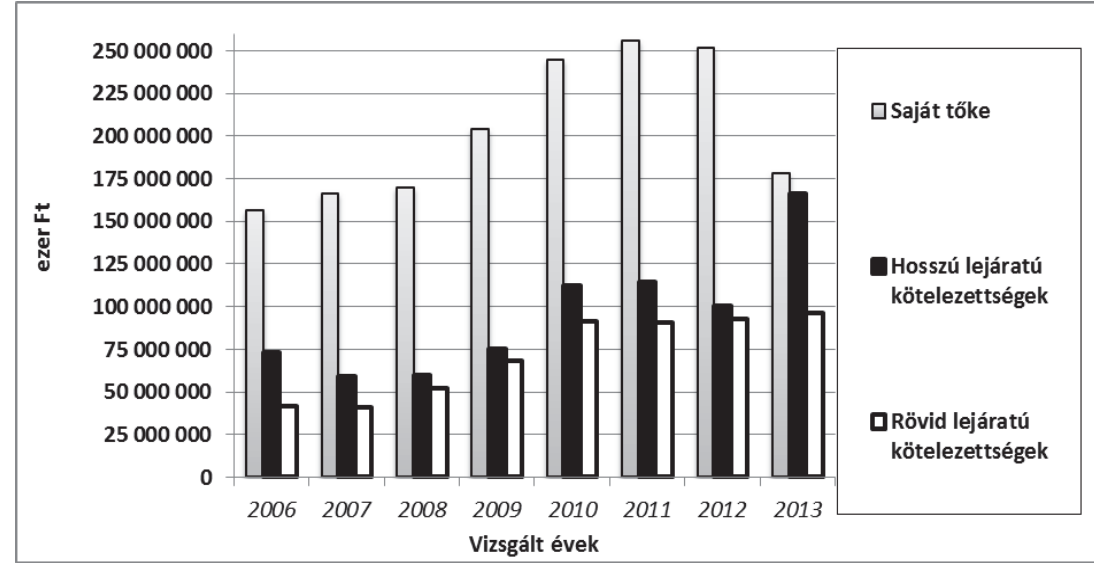

Forrás: saját kutatás, 2015

\section{EREDMÉNYEK}

\section{Megyei jogú városok}

A minta elemszámok tükrében nem meglepő fejlemény, hogy az aggregált tőkeszerkezetből a legjelentősebb részesedést a megyei jogú városok önkormányzatainak vállalatai képezik.

Ha a megyei jogú városok által birtokolt cégek saját tőkét vizsgáljuk megállapítható tendencia, hogy 2006-2008 között kismértékű, 2009-2012 között dinamikusan emelkedett a vizsgált vállalati kör saját tőkéjének értéke, de a 2013as év tekintetében tőkeátrendeződést lehet megfigyelni, a saját tőke drasztikusan csökkent, míg a hosszú lejáratú kötelezettségek növekedtek. A saját tőke növekedési üteme nominális értéken - 2008 és 2011 között reálértéken számítva is növekedett, tehát a megyei jogú városok vállalatai nagyobb mértékben tudták növelni saját tőkéjüket, mely a tulajdonosok tőkejuttatásának köszönhető.

Ehhez kapcsolódóan megvizsgáltam, milyen mértékben befolyásolta a saját tőke értékének növekedését az aggregált eredmény. Ennek értékeléséhez az adózott - és mérleg szerinti eredményeket vizsgáltam az aggregált adatokból, ezen értékeket a 2. táblázatban ismertetem.
Ahogyan látható, a saját tőke növekedését nem magyarázza meg az összesített adózott eredmény, sem a mérleg szerinti eredmény alakulása, mivel a jelentős növekedés éveiben (2009-2011 vonatkozásában) nem volt akkora mértékü, mely magyarázta volna a saját tőke növekedését, ebből azt a következtetést lehet levonni, hogy a tulajdonosok nagymértékü tőkejuttatást valósítottak meg.

Ehhez kapcsolódóan megvizsgáltam a korrigált jegyzett tőke alakulását (az önkormányzati részesedés és a jegyzett tőke szorzatát), mely értékeinek alakulása, 2008-tól 2010-ig 30,7\%-os növekedést produkált, így igazolja megállapításaim, a saját tőke növekedésének forrását illetően.

Összességében tehát megállapítható, hogy az önkormányzati tulajdonú gazdasági társaságok szerepe, és mérete emelkedett a vizsgált periódusban a megyei jogú városok körében, akárcsak az összes vállalat adatát figyelembe véve, melyet a saját tőke növekedéséből lehet leszűrni, ugyanakkor az utolsó vizsgált évben drasztikus változások történtek.

A hosszú lejáratú kötelezettségek változásait vizsgálva megállapítható, a választási évben magasabb, majd csökkenő tendenciát követ, a kiugró 2013-as évet figyelmen kívül hagyva. 
Ugyanakkor fontos tapasztalat, hogy a megyei jogú városok idegen tőkéjének megoszlásában a hosszú lejáratú kötelezettségek dominánsak minden vizsgált évben. Ez a sokrétűbb feladatmegoszlással magyarázható, a fővárosi önkormányzathoz hasonlóan. Megvizsgáltam, hogy a mérlegek adataiból milyen tényezők magyarázhatják a tartós idegen forrásállomány bővülését.

A leginkább érdekes az ágazati tőkeszerkezetek tekintetében a víziközmú ágazat, hiszen a tartós források szerkezete 2012 és 2013 között szinte megcserélődött. A szignifikáns változás oka, hogy a víziközmú-szolgáltatásról szóló 2011. évi CCIX. törvény 6.§ (1) -mely kimondja, hogy víziközmú kizárólag az állam és települési önkormányzat tulajdonába tartozhat - 2013. január 1-jén a részvénytársaságban megtestesülő vagyona az ellátásért felelős települési önkormányzatokra - a rendszer független víziközmű-elemek kivételével átháramlott, így tulajdonképpen egy vagyonátrendeződés történt az önkormányzati gazdaság szereplői között. Idézett törvény $7 . \S$ lehetővé teszi a szolgáltató részére lehetővé teszi a szolgáltató felé történő elidegenítést, illetve a (2) a víziközmű-szolgáltató a tulajdonában lévő rendszerfüggetlen víziközmúelemet számviteli elszámolásaiban az egyéb saját tulajdonú eszközeitől elkülönítetten tartja nyilván, és gondoskodik a szükségessé váló felújításáról, pótlásáról.

Mivel sajnos minden vállalat esetében nincs rendelkezésre álló információ minden vállalat esetében a hosszú lejáratú kötelezettségek állományának változásáról, kíváncsi voltam, milyen mértékben történt önkormányzatokhoz hasonlóan kötvénykibocsátás a vállalati szektorban. A vizsgált vállalatok közül a vizsgált periódusban mindössze 8 vállalat választotta a kötvénykibocsátást, mint külső finanszírozási forrást, vélhetően a tulajdonosok forrásszerzésével egyetemben, így a banki finanszírozás, illetve lízing a domináns.

Végül megvizsgálva a tőkeszerkezet harmadik elemét, a rövid lejáratú kötelezettségek értékét. Az összesített értékkel összevetve konstatálható, hogy a megyei jogú városok vállalatainak körében nem a rövid lejáratú kötelezettségek képezik a legnagyobb csoportot a kötelezettségek állományán belül, hanem a hosszú lejáratú kötelezettségek. Ahogyan látható, 2010-től növekedtek a rövid lejáratú kötelezettségek, de párhuzamosan a forgóeszközök növekedésével egyetemben.

A változások tendenciáját megvizsgálva levonható az a következtetés, hogy 2007-tól folyamatos növekedés, majd 2010-től stagnálás következik be az összesített adatokban.

2006-ös érték magasabb, mint azt megelőző, így a beruházások finanszírozásának igénybevételéhez növekedhetett meg az átmeneti forrás szükséglet. 2010-től nagyjából stagnál a rövid lejáratú kötelezettségek értéke, mely magyarázható a válság eredményképp létrejövő romló fizetési morállal az érintett ágazatokban, illetve a finanszírozó önkormányzatok esetében, a folyamat a forgóeszközök hasonló irányú változását kísérte, így a finanszírozás biztosítása érdekében növekedett a rövid lejáratú kötelezettségek értéke.

\section{2. táblázat: A megyei jogú városok vállalatainak aggregált mérleg és eredménykimutatás}

adatai

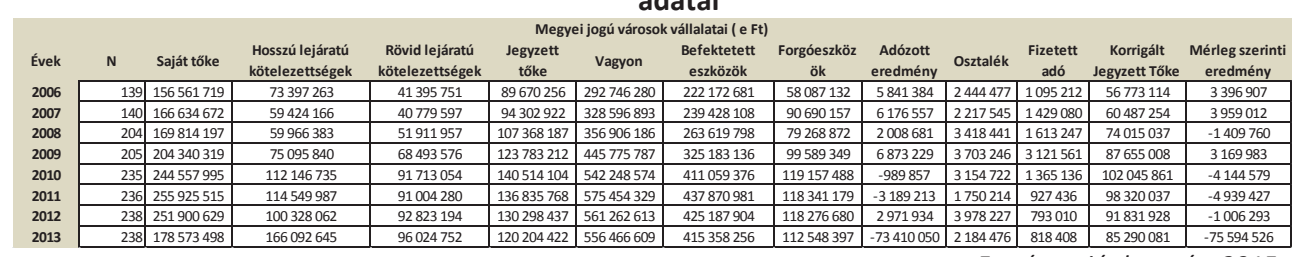

Forrás: saját kutatás, 2015 
A 2. táblázat adatai alapján megállapíthatjuk, hogy az önkormányzati cégek vagyona a vizsgált periódusban erős növekvő tendenciát követ, 2011-es csúcsértékkel, utána kisebb csökkenő tendenciával, tehát a vagyon növekedésében elsődlegesen a tartós források játszottak domináns szerepet.

Mivel a finanszírozás logikája szerint a tartós források a tartós eszközöket finanszírozzák, így a befektetett eszközök alakulását is megvizsgáltam. Azt a következetést vontam le, hogy a vagyonalakulás pályájához hasonló tendenciák rajzolódnak ki, így jelentősen növekedett a befektetett eszközök aránya szintén 2011-es csúcsponttal. Az önkormányzati vállalatok vagyona értéken számítva a kezdeti vizsgált évtől 2011-ig 282 milliárd Ft-tal, míg a befektetett eszközök értéke összesen 215 milliárd Ft-tal növekedett, mely az összes vállalati növekmény döntő hányadát a megyei jogú városok vállalatai adják.

Mindebből azt a következtetést lehet levonni, hogy a vagyon növekedésével egyetemben a tartós eszközök értéke is nagymértékben növekedett, így a beruházások finanszírozásában egyre nagyobb szerep hárult a hosszú lejáratú kötelezettségekre megyei jogú városok körében. Ugyanakkor a fedezeti mutatókat megvizsgálva is igazolódik a felvetés, hiszen egyre kevésbé finanszírozza az idősorban a tartós eszközöket, így inkább agresszív irányba módosul a finanszírozás stratégiája.

\section{Föváros}

\section{2. ábra: A Fővárosi önkormányzat aggregált vállalati tőkeszerkezeti adatai}

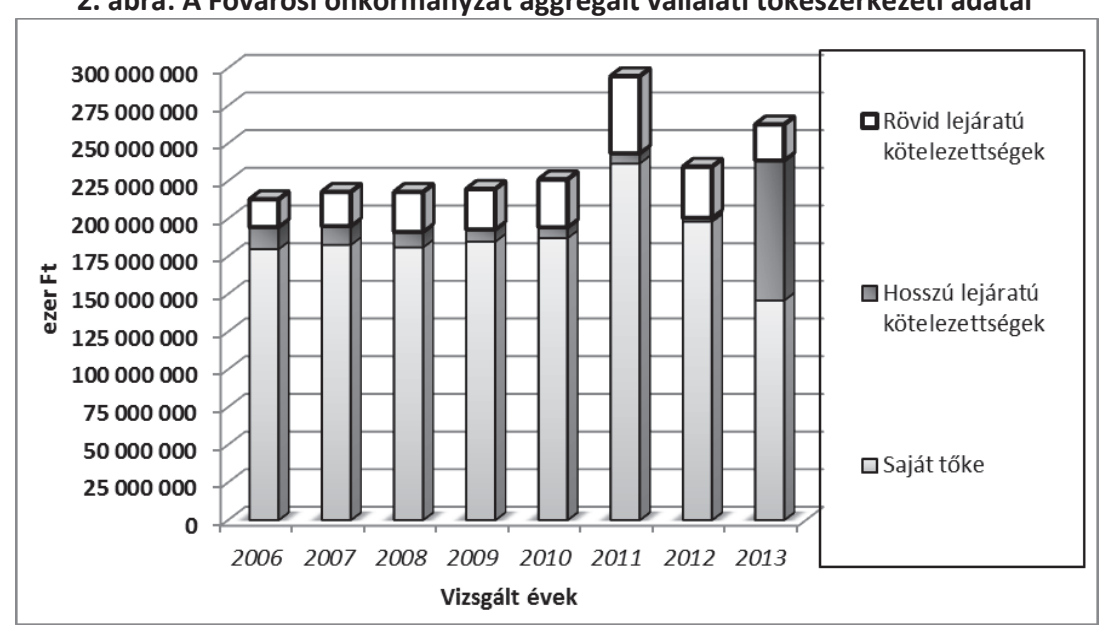

Forrás: saját kutatás, 2015

A fővárosi tulajdonú gazdasági társaságok szintén a másik jelentős szegmenst képviselik a vizsgált településtípusok vállalatai tekintetében, de szerepe egyre inkább csökkenő tendenciát követ a saját tőke tekintetében, hisz 2006-tól 2013-ig majdnem 10\%-ot esett vissza a részesedésük az összes vállalatot figyelembe véve, tehát a megyei jogú városok vállalatain túl a második legnagyobb szegmenset alkotják a
Fővárosi önkormányzat birtokában lévő gazdasági társaságok.

Hosszú lejáratú kötelezettségek tekintetében a részesedés már jóval kisebb, az állomány döntő hányada - ahogyan megállapításra került - a megyei jogú városoknál képződött.

A 2. ábra jól mutatja, hogy a fővárosi önkormányzati tulajdonában lévő vállalatok 
aggregált értéke alapján a hosszú lejáratú kötelezettségek állománya csak igen kismértékú az összes vagyon arányában, melyet igazol, hogy 2006-ot, illetve a megyei jogú városok esetében már tapasztalt 2013-as vagyonátrendeződést leszámítva folyamatos csökkenő tendenciát követ, 2012-ben már 1\% alá csökken, értéken pedig 14 milliárd Ft-ról 2 milliárd Ft-ra csökken a hosszú lejáratú kötelezettségek aránya.

E folyamat ellentétben áll a megyei jogú városok vállalataival, ahol az idegen tőkében a hosszú lejáratú kötelezettségek domináltak. Szintén érdekesség, hogy az aggregált adatokkal, illetve a megyei jogú városok vállalatainál tapasztaltakkal ellentétben nem érvényesül sem a megfigyelt ciklushatás, hiszen a 2006-os évet követően folyamatosan csökken, és a választási évben, 2010-ben sem emelkedett meg drasztikusan, sőt 7\%-al csökkent az előző évhez képest.

Instrumentumok tekintetében, mivel sok esetben egymással kapcsolatban lévő vállalatokról van szó, 2011-es évet megelőzően jelentősnek tekinthető volt a vállalatok közti finanszírozás, mely lehetővé tette a veszteséges tevékenységek keresztfinanszírozását. (2012-től konszolidált adatok vannak figyelembe véve a BVK csoport tagjai esetében.)

Tehát az eladósodás mértéke nem tekinthetó jelentősnek, mely az önkormányzat kontrollnak köszönhető, a tapasztalható tendenciák az összesített értékben, illetve a megyei jogú városok esetében tapasztaltakkal szemben csak a 2013-as vagyonátrendeződés esetében tapasztalható, mely sokkal drasztikusabb mértékú, mint a megyei jogú városok esetében, hiszen az előző évi adat 35-szörösére emelkedett.

A saját tőke mértékének változása kiegyensúlyozottan alakul, 2011-ben történt számottevő kiugrás az adatok értékében. Ennek magyarázata, hogy 3 jelentős cégalapítás következett be, tehát nagymértékű volt az önkormányzati forrásjuttatás, hiszen egészen 2011-ig csak kismértékű 1-1,5\% évi növekedési ütem volt megfigyelhető, ugyanakkor 2012-től kezdődően a visszaesés sokkal nagyobb mértékű, mint a megyei jogú városok, illetve az összesített adatoknál.

Szintén nem nyújt magyarázatot az, mérleg szerinti eredményből származó saját tőke növekedése, hiszen ezek értéke a magas adózott eredmény ellenére negatív, a tőkenyújtás mellett a Fővárosi Önkormányzat mintegy 25 milliárd Ft osztalékot vett fel a 2011-es évben (3. táblázat). A vagyoni portfolióban egyébként folyamatosan emelkedett a Főváros részesedése, a vizsgált időszak végére már $85 \%$ felett volt önkormányzati tulajdonban a vagyonportfolió. A korrigált jegyzett tőke növekedése jelentős mértékű, bár mértékét tekintve nem éri el a megyei jogú városok esetében tapasztaltakat, a növekedés értéke 63 milliárd Ft a kezdő évhez képest, melyet az új vállalatok alapítására fordított az önkormányzat.

A rövid lejáratú kötelezettségeket vizsgálva megállapítható, hogy 2006-tól kezdődően folyamatosan növekedtek, 2011-es évig. A növekedésben kulcsszerep jutott a szállítói finanszírozásnak jut kulcsszerepet a rövid lejáratú hitelállomány mellett. Magyarázatként szolgál, hogy a 2009-től kezdődő dinamikus emelkedés során a hiteleket inkább a szállítói finanszírozás váltotta fel, melyet indokolhat a vállalatok méretükből fakadó nagyobb alkupozíciója.

$\mathrm{Az}$ állomány növekedésének hátterében a lakosság fizetési nehézségei állhatnak, ahogyan a korábbi vizsgálataim során tapasztalható volt, különösen a közüzemi ágazatokban. Ezzel párhuzamosan a forgóeszközök aggregált értékű nagyobb volumenű növekedése követte, mely a finanszírozási szerkezet változásának romlása nem követte. 
2. táblázat: A Fővárosi önkormányzat vállalatainak aggregált mérleg és eredménykimutatás adatai

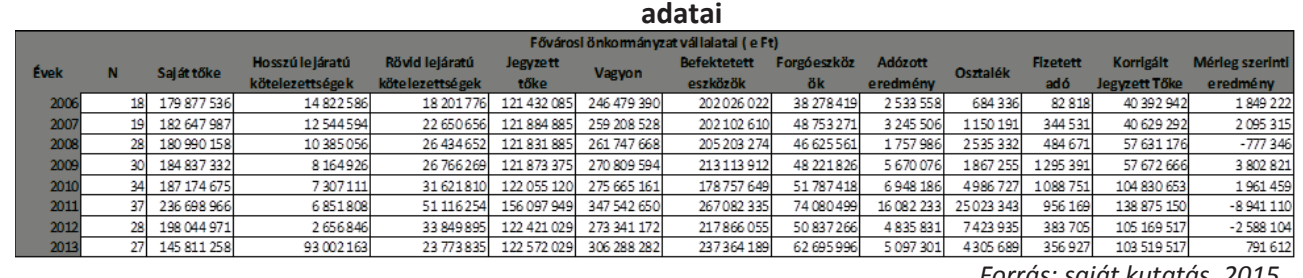

Forrás: saját kutatás, 2015

A vagyon alakulását vizsgálva levonható az a konzekvencia, hogy a vagyon folyamatosan növekszik a Főváros vállalatainál, de a növekedés kisebb mértékú, mint a megyei jogú városok cégei esetében, illetve az utolsó vizsgált évben tapasztalt visszaesés sem érvényesül, hiszen az utolsó évben növekedést mutat, ebben a tényezőben nem az átmeneti vagyonelemek mutatják (aktív és passziv időbeli elhatárolások). A vagyonnövekedés mértéke nem éri el a megyei jogú városoknál tapasztaltakat, hiszen a növekedés értéke 2006tól 2011-ig 101 milliárd Ft-ot tesz ki, a kisebb 2012-es visszaesést követően az érték 59,88 milliárd Ft értékú, így is számottevő növekedést produkált az önkormányzati vállalatok vagyona, értékében összhangban a tiszta önkormányzati tulajdon mértékével.

A befektetett eszközök alakulását vizsgálva, megállapítható a tapasztalat, hogy jóval kisebb mértékben növekedett, mint a méretében hasonló megyei jogú városok esetében. Ennek oka, hogy a megyei jogú városok tekintetében nagyobb mértékú volt a vállalatalapítás, míg a megyei jogú városok esetében majdnem megduplázódott, a Főváros esetében a növekedés mértéke a $20 \%$-ot meghaladó volt.

Az illeszkedési elvet vizsgálva, a tartós források a Fővárosi önkormányzati vállalkozások esetében elég hektikusan alakultak, azonban értékük közel esett az illeszkedési elvet jelentő 1-es értékhez, az időszak végére el is érték.

Érdekessége a fővárosi cégeknél tapasztaltaknak, hogy az adózott eredmény pozitív értéket vett fel minden vizsgált évben, ellentétben a megyei jogú városokkal, ahol utolsó négy évben a cégek veszteségesek voltak, míg a megyei jogú városoknál tapasztalt nagymértékú negatív értékkel szemben is.

\section{KÖVETKEZETÉSEK, ÖSSZEFOGLALÁS}

\section{4. táblázat: A hipotézisek vizsgálata}

\begin{tabular}{|ccc|}
\hline Szegmensek/Hipotézisek & Megyei jogú városok & Föváros \\
\hline 1. hipotézis & $\begin{array}{c}\text { Beigazolódott, mindkét } \\
\text { kötelezettségtipusra vetitve }\end{array}$ & $\begin{array}{c}\text { Részben beigazolódott, de } \\
\text { csak a hosszú lejáratú } \\
\text { kötelezettségek 2013-as } \\
\text { emelkedése miatt a hosszú } \\
\text { lejáratú kötelezettség } \\
\text { esetében }\end{array}$ \\
2. hipotézis & Elutasitásra került mindkét \\
kötelezettségtípusban & $\begin{array}{c}\text { Részben, a rövid lejáratú } \\
\text { kötelezettségek } \\
\text { vonatkozásában } \\
\text { beigazolódott }\end{array}$ \\
3. hipotézis & Beigazolódott részben a hosszú \\
& lejáratú kötelezettségek \\
vonatkozásában & $\begin{array}{c}\text { Elutasításra került mindkét } \\
\text { kötelezettségtípus esetében. }\end{array}$ \\
& & \\
\hline
\end{tabular}

Forrás: saját kutatás, 2015 


\section{Megyei jogú városok}

A felállított hipotézisek eredményeképp úgy gondolom, alaphipotézis teljesült, hiszen a forrásállomány növekedett, de nem a tulajdonos önkormányzatokhoz hasonló mértékben, melyet jól mutat, hogy a saját tőke növekedése erőteljesebb volt a megyei jogú városok körében (2006-2012 között 95 milliárd).

$\mathrm{Az}$ második hipotézist elvetem, hiszen az ábrákból, és a bemutatott értékekből világosan látszik, hogy nem érvényes a Roxburgh hipotézise, nem következett be visszaesés a válság hatására, sokkal inkább a politikai ciklushatás érvényesül, hisz a választást követő években csökken az hosszú lejáratú kötelezettségek értéke, aránya egyaránt, de a ciklushatásnál szerepet játszott az EU-s fejlesztések igénybevétele is, ha 2013-as év adatait nem vesszük figyelembe.

\section{Főváros}

Az alaphipotézis megállja a helyét, de csak a 2013-as év kiugró adatai miatt, mely hasonlóan a megyei jogú városok cégei esetében tapasztaltaknál a víziközmű vagyon visszaháramlásából következik be. Ha ezt az évet figyelmen kívül hagyjuk, abban az esetben a folyamatos csökkenésből adódóan a hipotézis elvetése mellett kellene döntenünk.

A második hipotézis esetében amiatt igazoldott be, mivel 2011-ig növekedett, majd visszaesett a rövid lejáratú kötelezettségek értéke, így a Roxburgh hipotézis feltételezései teljesülnek. A beruházási ciklushatás egyik kötelezettségtípus esetében sem érvényesült a Főváros tekintetében, hiszen a rövid lejáratú kötelezettségek növekedtek, míg a hosszú lejáratú kötelezettségeknél monoton csökkenést mutatott a 2013. évig.

\section{IRODALOMJEGYZÉK}

[1.] Állami Számvevőszék (2011): Jelentés az önkormányzatok ellenőrzéséről.

[2.] Hegedüs J. - Tönkő A. (2007): Az önkormányzati gazdasági társaságok szerepe a helyi önkormányzatok vagyongazdálkodásának- A feltételes kötelezettségvállalás problémája Családi Ezüst. Tanulmányok az önkormányzati vagyongazdálkodás témaköréből, Budapest 67-95

[3.] Polackova, H. (1998): „Contingent Government Liabilities: a Hidden Risk for Fiscal Stability."

[4.] Policy Research Working Paper, World Bank, Washington, D.C.,

[5.] Schick, A. (1999): Budgeting for Risk Washington, D.C.: World Bank.

[6.] Lentner Cs. (2014): A magyar önkormányzatok adósságkonszolidációja. Pénzügyi szemle, 2014. (59. évf.) 3. sz. 330-344. old.

[7.] Sisa K. - Veress A. (2014): Felmérés a települési önkormányzatok tervezési módszereiről

[8.] Statisztikai szemle, 2014. (92. évf.) 5. sz. 447-473. old.

[9.] Szabó I. (2012): Az önkormányzati tulajdonú gazdasági társaságok szerepvállása a költségvetési szektoron kívül feladatellátásban a megyei jogú városok önkormányzatainál. Doktori Értékezés, Győr

[10.] Szemán Judit (2013): A válság hatása a magyar vállalatok tőkeszerkezetére, különös tekintettel a hitelállományra. Controller Info 2013/10. szám 20-27.old. 
[11.] Vigvári A. (2008): A közszektor modernizálásának kulcsa az önkormányzati rendszer átalakítása. In: Önkormányzatok gazdálkodása - Helyi fejlesztés. Pécsi Tudományegyetem Közgazdaságtudományi Kar, Pécs, 80-97. p.

[12.] Vigvári A. (2009): Atipikus önkormányzati eladósodás Magyarországon. Közgazdasági Szemle 2009/ 7-8. 708-730. 177-195

[13.] Vigvári A. - Jánossy D. (2009): Kockázatok az önkormányzati rendszerben, ÁsZKUT, Budapest

[14.] 2011. évi CLXXXIX. törvény Magyarország önkormányzatairól 